\title{
The late Holocene decline of Trapa natans L. in Northern Poland in the light of new palaeobotanical and geochemical data
}

\author{
Agnieszka Lewandowska ${ }^{1^{*}}$, Przemysław Niedzielski $^{2}$, Mariusz Gałka $^{3}$ \\ ${ }^{1}$ Department of Biogeography and Palaeoecology, Adam Mickiewicz University in Poznan, Krygowskiego 10, 61-680 Poznań, Poland, \\ e-mail: agmole@amu.edu.pl (* corresponding author) \\ ${ }^{2}$ Department of Analytical Chemistry, Adam Mickiewicz University in Poznan, Umultowska 89, 61-614 Poznań, Poland, \\ e-mail: pnied@amu.edu.pl \\ ${ }^{3}$ Department of Geobotany and Plant Ecology, University of Lodz, Banacha 12/16, 90-237 Łódź, Poland, \\ e-mail: mariusz.galka@biol.uni.lodz.pl
}

\begin{abstract}
Trapa natans (water chestnut) is an aquatic, thermophilic plant whose decline has been observed in many localities in central Europe during the last decades. In this paper, we present a description of two new T. natans subfossil sites located outside its present northern distribution in Poland. High-resolution analysis of plant macrofossils supported by geochemical analysis were undertaken to reconstruct the palaeoecological habitat and examine the cause of the late Holocene decline of T. natans that took place ca. 4000 calibrated years before AD 1950 (cal. yr BP) in a paleolake, presently the Bagno Kusowo bog. Its disappearance was a consequence of terrestrialisation and the development of peatland. In paleolake sediments covered by the peat layer in the Mechacz Wielki bog, T. natans macrofossils were found from before ca. $3300 \mathrm{cal}$. yr BP. The decline of T. natans could have resulted from the changes and development of other plant communities where the dominant role was played by Stratiotes aloides and Nymphaea sp. In our study sites, T. natans occurred together with Potamogeton crispus, Potamogeton obtusifolius, Nymphaea alba, and Nuphar sp. in eutrophic water dominated by $\mathrm{Ca}^{2+}$, $\mathrm{Fe}^{3+}$, and $\mathrm{Al}^{3+}$ ions. Our palaeobotanical and geochemical results align with the contemporary conditions of T. natans habitat.
\end{abstract}

Key words: water chestnut, plant macrofossils, palaeoecology, geochemical sediment analysis

\section{Introduction}

Over the last several thousand years, many aquatic plants have changed their range of distribution in Europe due to climate change and human activity, e.g., the inflow of pollutants into water reservoirs causing changes in the water quality and eutrophication (Piórecki 1980; Bradshaw and McNeilly 1991; Zając and Zając 2001; Nienhuis et al. 2002; Berglund et al. 2008; Yang 2008; Martín-Closas 2013; Väliranta et al. 2015; Marquer et al. 2017). Moreover, for several centuries, with the increase in human migration and the development of communication routes, the number of invasive alien aquatic plant species such as, Elodea canadensis, has increased in European freshwater ecosystems, with an ecological and economic impact (Hussner et al. 2017). Autogenous processes such as natural succession and competition among plants are also important factors in aquatic ecosystems (Zetter and Ferguson 2001; Kamiński 2012). All these factors contribute to a decreasing natural macro- phyte community and a withdrawal of rare and valuable aquatic species (Zetter and Ferguson 2001; Kamiński 2012; Hussner et al. 2017). In many cases, changes in the plant communities are so advanced that it is difficult to determine what is native for some ecosystems. For this reason, it is important to know the time of the appearance and disappearance of various plants and the impact of autogenous and allogeneic factors that have triggered changes in aquatic ecosystems. Palaeoecological studies and many methods used in this research, e.g., plant macrofossils, pollen and geochemical analysis, provide an overview of plant cover changes and their migration routes, and they help determine past environmental conditions (Lang 1994; Davidson et al. 2005; Normand et al. 2011; Martín-Closas 2013; Gałka et al. 2014; Kołaczek et al. 2017). Apart from this approach, detailed studies of accumulated lake deposits are important sources of professional knowledge that can be applied during management and environmental protection and restoration of highly changed and damaged aquatic ecosystems (Tor- 
nadore et al. 2000; Baldantoni et al. 2004; Staniszewski and Zielnica 2006; Herbichowa et al. 2007; Smieja and Ledwoń 2013; Petrović et al. 2016; Ławicki et al. 2017).

At present, many rare aquatic species are endangered or declining and are protected by law. One of these plants is Trapa natans L. (water chestnut), for which a decline has been recorded over several decades in Northern and Central Europe (Kaźmierczakowa and Zarzycki 2001; Džigurski et al. 2012). T. natans is an aquatic plant that is considered a thermophilic species, and its distribution area in the past was much larger (Zetter and Ferguson 2001; Piękoś-Mirkowa and Mirek 2003; Olszewski and Markowski 2014; Bryl et al. 2016). In palaeoecological reconstructions $T$. natans plays an important role as an indicator of warmer climatic stages because its fossil presence (nut remains and pollen) is usually recorded during the Holocene Climate Optimum (ca. 9000-5000 cal. yr BP) in Europe (Samuelson 1934; Szafer 1954; Godwin 1975; Flenley et al. 1975; Lang 1994; Korhola and Tikkanen 1997; Magyari et al. 2008; Miotk-Szpi-

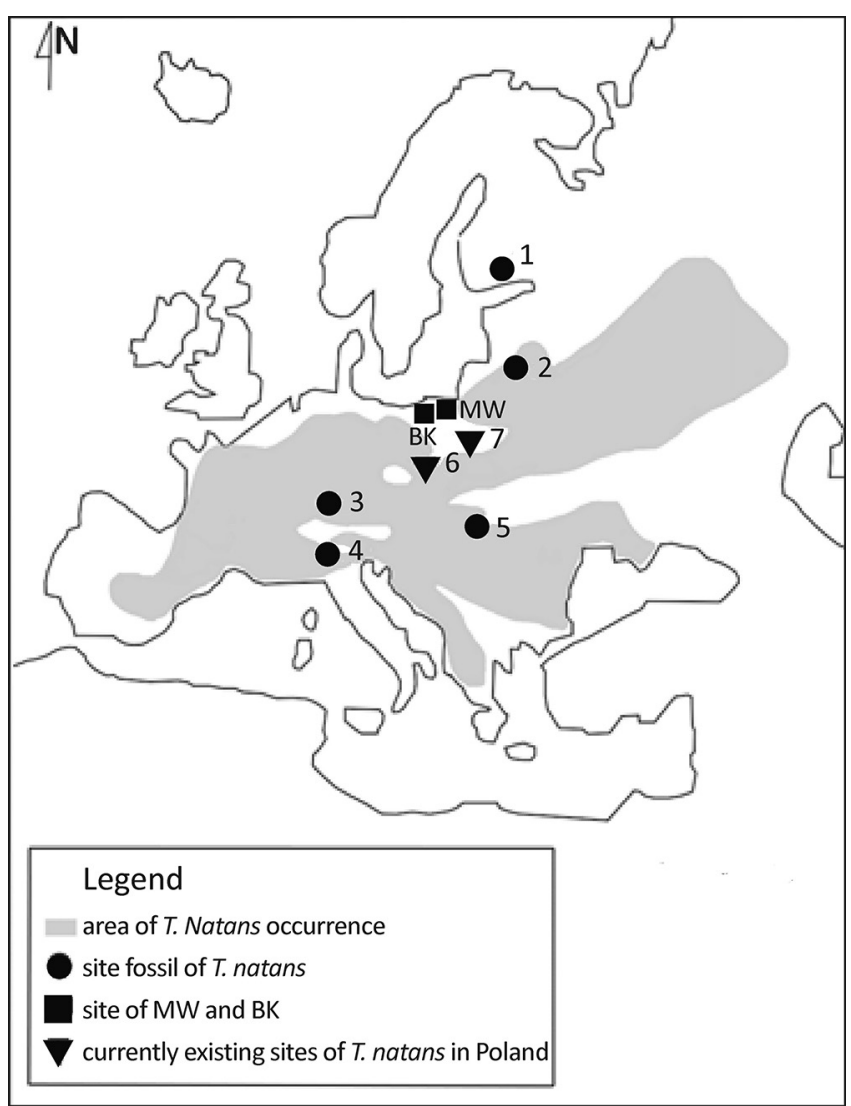

Fig. 1. Setting of the study site and the location of palaeoecological and contemporary records of T. natans presence mentioned in the text: BK - Bagno Kusowo (Poland), MW - Mechacz Wielki (Poland). Location of the sites mentioned in the text: 1 - Pyysuo Lake (Finland), 2 - Burtnieks Lake (Latvia), 3 - Federsee Lake (Germany), 4 - Molino Casarotto (Italy), 5 - plain Bereg (Hungary), 6 Szumirad Lake (Poland), 7 - Opatkowickie Lake (Poland) ganowicz and Gałka 2009). Presently, T. natans occurs in southern, central and eastern Europe, and its range in the north covers northern France and stretches to $57^{\circ} \mathrm{N}$ in Central Russia (Fig. 1) (Zając and Zając 2001; Olszewski and Markowski 2014). In Poland, T. natans is found in the upper and central stretches of the Vistula, Oder and San rivers (Piękoś-Mirkowa and Mirek 2003; Jakubowska and Kazuń 2005; Krechowski et al. 2009; Bryl et al. 2016). In the XIX and XX centuries, the northern limit of distribution of T. natans moved significantly south in Poland (Piórecki 1980). It is estimated that approximately 180 plant sites disappeared during this period (Piękoś-Mirkowa and Mirek 2003).

T. natans belongs to the Trapaceae family. It is an annual aquatic plant, rooted at the bottom of a water body, with leaves floating over the surface (Piórecki 1980; Zetter and Ferguson 2001; Krechowski et al. 2009). The plant predominantly grows in shallow, eutrophic water bodies as well as in stagnant and slowmoving water, usually $120-200 \mathrm{~cm}$ deep, with clay-silt or mud bottoms, neutral or slightly alkaline $\mathrm{pH}$, and significant nitrogen content (Kłosowski and Tomaszewicz 1996). T. natans is a photophilic and thermophilic species (Piórecki 1980; Kostrakiewicz and Kozak 2009). Because of their high nutrient content, T. natans nuts have been used as food by both humans and animals for centuries (Kuneś et al. 2008; Łuczaj 2008; Karg 2013). In folk medicine, it is considered a medicinal plant (Arima et al. 1999; Ali and Javed 2014; Bharthi et al. 2015).

It is typical for T. natans to form monospecies communities. It can also be found with other plants, e.g., Potamogeton sp., Ceratophyllum spp., Myriophyllum spicatum, Nuphar lutea, Nymphaea alba, Salvinia natans, Spirodela polyrhiza, and Lemna sp. These plants develop rapidly in shallow water and compete with $T$. natans, pushing them into deeper water unfavourable for development above $200 \mathrm{~cm}$ (Zetter and Ferguson 2001). However, in smaller and shallower reservoirs, $T$. natans may become the dominant plant (Piórecki 1980; Perzanowska 2012).

In this paper we present the results of high-resolution, contiguous plant macrofossil analysis of four cores and geochemical analysis of three cores taken from paleolakes located in northern Poland with the following aims: (i) to determine the age and reasons for the decline of T. natans; and (ii) to reconstruct the palaeoecological habitat of T. natans.

\section{Material and methods}

\section{Coring and subsampling, chronology of the core}

Coring and sampling were undertaken in 2011 using a Russian peat corer (Instorf type), with a $7 \mathrm{~cm}$ diameter and $100 \mathrm{~cm}$ length. The sediments including 
Table 1. Radiocarbon dates from Mechacz Wielki (MW) and Bagno Kusowo (BK) bogs (after Lamentowicz et al. 2015; Gałka et al. 2017)

\begin{tabular}{|c|c|c|c|c|}
\hline Depth & \multirow{2}{*}{ Material } & \multirow{2}{*}{ Laboratory Nr. } & \multirow{2}{*}{ AMS date } & Age \\
\hline [cm] & & & & [cal. yr BP] \\
\hline MWI 518 & 10 fruits of Carex pseudocyperus, 2 fruits of Betula pubescens & Poz-44490 & $1875 \pm 35 \mathrm{BP}$ & $1885-1720$ \\
\hline MWII 475 & $\begin{array}{l}5 \text { fruits of Carex rostrata, } 1 \text { fruit of Carex pseudocyperus, } 2 \text { fruits of Betula } \\
\text { pubescens, } 1 \text { fruits of Sparganium }\end{array}$ & Poz-44491 & $2005 \pm 30 \mathrm{BP}$ & $2038-1883$ \\
\hline MWII 571 & Picea abies seed wing's and periderm & Poz-52364 & $3125 \pm 35 \mathrm{BP}$ & $3443-3238$ \\
\hline BKI 795 & 25 fruits of Carex rostrate & Poz-44492 & $3665 \pm 35 \mathrm{BP}$ & $4090-3891$ \\
\hline BKII 795 & Sphagnum stems & Poz-48361 & $3010 \pm 30 \mathrm{BP}$ & $3335-3077$ \\
\hline
\end{tabular}

peat and gyttja layers were placed in PVC tubes and wrapped in plastic foil. In the laboratory, the sediment was unpacked, cleaned and sliced into $1 \mathrm{~cm}$ slices using a scalpel. The core chronology was based on AMS (accelerator mass spectrometry). Radiocarbon dating was carried out at the Poznan Radiocarbon Laboratory. The calibration of the radiocarbon dates and the construction of the age-depth models was performed with $\mathrm{Ox}$ Cal 4.1 software (Bronk-Ramsey 2009) and the IntCal13 curve (Reimer et al. 2013). Five samples from four cores were used to determine the time of deposit accumulation (Lamentowicz et al. 2015; Gałka et al. 2017).

In this paper, we present the results of the analysis of the bottom parts of the cores covering lake deposits. The tests of cores in MW were investigated at a depth of 470 $\mathrm{cm}$ to $600 \mathrm{~cm}$ and in BK at a depth of 790-900 cm. The results of the detailed multi-proxy palaeoecological studies covering the entire peat layer sand sequence and most of the upper part of the lake sediments in MW as well as the peat layers in $\mathrm{BK}$, have already been published: MW (Gałka et al. 2017) and BK (Lamentowicz et al. 2015).

\section{Study sites}

The studied paleolakes are located in northern Poland where the Mechacz Wielki (MW) and Bagno Kusowo (BK) Baltic raised bogs are presently developed (Fig. 1).

The MW bog is situated in north-eastern Poland in

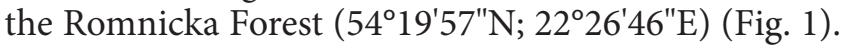
This bog is situated in a basin with a surface area of 174 ha and is dewatered through a small river, the Czarna Struga. The eastern part of the peat bog is frequently flooded by water from the upper regions and the catchment. The central part is characterized by lower fertility and higher acidification (Żurek and Kloss 2012).

The present-day vegetation covering the peat bog has varied character. The central part (markedly uplifted) is characterized by lower nutrient concentration habitat overgrown with dwarf pine. Communities of Sphagnum magellanicum, S. rubellum and S. fuscum predominate in the peat bog. Empetrum nigrum and Rubus chamaemorus occur less frequently, and in the hollows, S. cuspidatum and S. balticum (Gałka et al. 2017).

During summer, the temperature system is influenced by the proximity of the Baltic Sea (average July temperature of $16-17^{\circ} \mathrm{C}$ ). In winter, the influence of the continental system (meaning January $-5^{\circ} \mathrm{C}$ ) is noticeable in MW. The average annual temperature is $+6.4^{\circ} \mathrm{C}$. The vegetation period is 190 days, and annual rainfall reaches $700 \mathrm{~mm}$. The winters are relatively long and frosty (Woś 1993).

The Baltic raised bog BK, located in north-central Poland (53⒋ $48^{\prime} 41^{\prime N}$; $\left.16^{\circ} 34^{\prime} 59^{\prime \prime} \mathrm{E}\right)$ (Fig. 1), is part of the Bagno Kusowo nature reserve. Sphagnum spp. and Eriophorum vaginatum play a dominant role (Lamentowicz et al. 2015). On the edge of the raised bog there is a swampy pine forest of Vaccinio uliginosi-Pinetum (Ciaciura and Wilhelm 2005).

The BK bog lies at the intersection of the Atlantic and continental climates. The climate is characterized by a relatively cool summer (average temperature in July $17-18^{\circ} \mathrm{C}$ ) and a rather mild winter (average temperature in January $0-2^{\circ} \mathrm{C}$ ) (Kondracki 2009; Cedro and Sotek 2016). The climatic conditions are temperate and mostly conditioned by the influence of polar and polar-continental air masses (Woś 1993).

The average annual air temperature is approximately $+8^{\circ} \mathrm{C}$. The growing season is approximately 200 days, and rainfall reaches $700 \mathrm{~mm}$.

\section{Palaeoecological analysis}

Plant macrofossils were analysed for $1 \mathrm{~cm}$ intervals in contiguous samples in four cores. The number of macroremains was calculated on the basis of the same sample volume, which was $25 \mathrm{~cm}^{3}$. The samples were rinsed under a warm-water current over 0.20 mesh screens. The vascular plant composition was determined on the basis of carpological remains and vegetative fragments (leaves, rootlets, epidermis) using the available identification keys (Tobolski 2000; Velichkevich and Zastawniak 2006, 2008). The macrofossils were identified with a Nikon SMA 800 stereoscopic microscope under 10-200A and an Olympus CX 41 light microscope. A total of 197 samples were analysed. The names of the plant species were adopted following Mirek et al. (2002).

\section{Geochemical analysis}

For the determination of selected elements, a 5110 ICP-OES (Agilent, USA) inductively coupled plasma 
with optical emission spectrometry was used. For multi-elemental determination, the common conditions were as follows: radio frequency (RF) power, $1.2 \mathrm{~kW}$, nebulizer gas flow, $0.7 \mathrm{~L} \mathrm{~min}^{-1}$, auxiliary gas flow, 1.0 $\mathrm{L} \mathrm{min}^{-1}$, plasma gas flow, $12.0 \mathrm{~L} \mathrm{~min}^{-1}$, viewing height for radial plasma observation, $8 \mathrm{~mm}$, detector CCD (charge coupled device) temperature, $-40^{\circ} \mathrm{C}$, and signal acquisition time, $5 \mathrm{~s}$ for 3 replicates. The detection limits were $0.01 \mathrm{mg} \mathrm{kg}^{-1}$ dry weight (DW) for all elements (as 3 -sigma criteria). The uncertainty for the total analytical procedure (including sample preparation) was $20 \%$. The traceability was checked using reference materials: CRM S-1-loess soil; CRM NCSDC (73349)-bush branches and leaves; CRM 2709-soil; CRM 405-estuarine sediments; and CRM 667-estuarine sediments. The recovery (80-120\%) was acceptable for most elements. For uncertified elements, recovery with the standard addition method was defined.

Plant macrofossils and geochemical data are presented in diagrams and plotted using C2 software (Juggins 2003).

\section{Results}

\section{Lithology and chronology}

Fine detritus olive gyttja was analysed in cores MW I, MW II and BK I. The core BK II lake sediment consisted of fine detritus olive gyttja at a depth of 800.5$809.5 \mathrm{~cm}$ and fine detritus brown gyttja at 809.5-849.5 $\mathrm{cm}$. Olive gyttja with visible $T$. natans chestnuts occurred at $819.5 \mathrm{~cm}, 828.5 \mathrm{~cm}$ and $838.5 \mathrm{~cm}$.

Based on the radiocarbon dates and the age-depth model, the analysed sediments containing T. natans macrofossils accumulated before ca. 3440-3240 cal. yr BP for MW and 4090-3890 cal. yr BP for BK.

\section{Macrofossil analysis}

\section{Mechacz Wielki}

Two zones of local vegetation development at MW I (Fig. 2A) and four zones at MW II were visually delimited (Fig. 2B). The core of MW I was analysed for $T$. natans macroremains (comparison of species of plants MW I with plants in MW II core). In the MW I core, $T$. natans remains were not recorded.

In zone MWI-ma-1 $(599.5-586.5 \mathrm{~cm})$, Nitella sp. oospores occurred most numerously and the individual remains of Nuphar sp. seeds.

The zone MWI-ma-2 $(586.5-550.5 \mathrm{~cm})$ was characterized by dominant aquatic plants, e.g., Potamogeton natans and Nymphaea alba, at a depth from 582.5 to $551.5 \mathrm{~cm}$. At the depth of $576.5-550.5 \mathrm{~cm}$, the remains of trees Alnus glutinosa, Populus tremula, Betula pubescens (maximum of amount), Pinus sylvestris and Picea abies were also found.
In zone MWII-ma-1 (600-587.5 cm), macroremains of aquatic plants e.g. T. natans, Stratiotes aloides, Nitella sp., Potamogeton obtusifolius and Nymphaea candida were recorded.

In zone MWII-ma-2 $(587.5-550.5 \mathrm{~cm})$, the dominant aquatic plants were Nitella sp., Nymphaea sp., and Stratiotes aloides also occurred.

The third zone MWII-ma-3 (550.5-485 cm) was characterized by the lack of T. natans and abundant species of aquatic plants: Nuphar sp., Cicuta virosa, Nymphaea candida and Potamogeton natans (numerous).

In zone MWII-ma-4 $(485-470 \mathrm{~cm})$, there was a lack of T. natans remains and the presence of Comarum palustre, Calliergon cordifolium (numerous), Carex pseudocyperus, Carex rostrata (numerous), Sparganium minimum and Scheuchzeria palustris. The remains of trees were found all over the analysed gyttja sequence: Pinus sylvestris, Picea abies and Betula pubescens.

\section{Bagno Kusowo}

Three zones at BK I (Fig. 3A) and two zones at BK II (Fig. 3B) in local vegetation development were visually delimited.

In the first zone, BKI-ma-1 $(899.5-837.5 \mathrm{~cm})$, aquatic plants such as T. natans, Nuphar sp., Nymphaea alba, Potamogeton crispus, Myriophyllum spicatum, Ceratophyllum demersum, and Nuphar lutea were recorded.

The second zone, BKI-ma-2 $(837.5-802.5 \mathrm{~cm})$, was characterized by an abundance of $T$. natans and single seeds of Nymphaea alba.

In zone BKI-ma-3 $(802.5-790.5 \mathrm{~cm})$, macrofossils of Carex pseudocyperus (numerous), Eleocharis palustris, Bidens tripartita, Scheuchzeria palustris, Carex rostrata, and Cicuta virosa were documented.

In the first zone, BKII-ma-1 $(850-808.5 \mathrm{~cm})$, T. natans was the dominant species. Twenty pieces of chestnuts and 66 pieces of harpoons were found (Fig. 3B). At the same depth, single remains of Nymphaea alba, Nuphar pumila and Nuphar sp. were identified.

In zone BKII-ma-2 (808.5-795 cm), T. natans and other aquatic plants disappeared. At a depth of 804.5 $\mathrm{cm}$, the remains of Andromeda polifolia seeds were found. The remains of the trees occurred throughout the entire core, most numerous was Pinus sylvestris.

\section{Geochemical analyses}

1. Mechacz Wielki

Five zones at MW I were visually delimited for present chemical elements (Fig. 4).

In zone MWI-gm-1 $(600-577.5 \mathrm{~cm})$, the dominance of $\mathrm{Ca}^{2+}\left(14010 \mathrm{mg} \mathrm{kg}^{-1}\right), \mathrm{Fe}^{3+}\left(8516 \mathrm{mg} \mathrm{kg}^{-1}\right)$ and $\mathrm{Al}^{3+}$ $\left(2074 \mathrm{mg} \mathrm{kg}^{-1}\right)$ was recorded. Other elements had low and medium values. The depth $(585.5-551.5 \mathrm{~cm})$ considerably elevated $\mathrm{Ca}^{2+}$ concentrations (13289 $\mathrm{mg} \mathrm{kg}^{-1}$ ), 


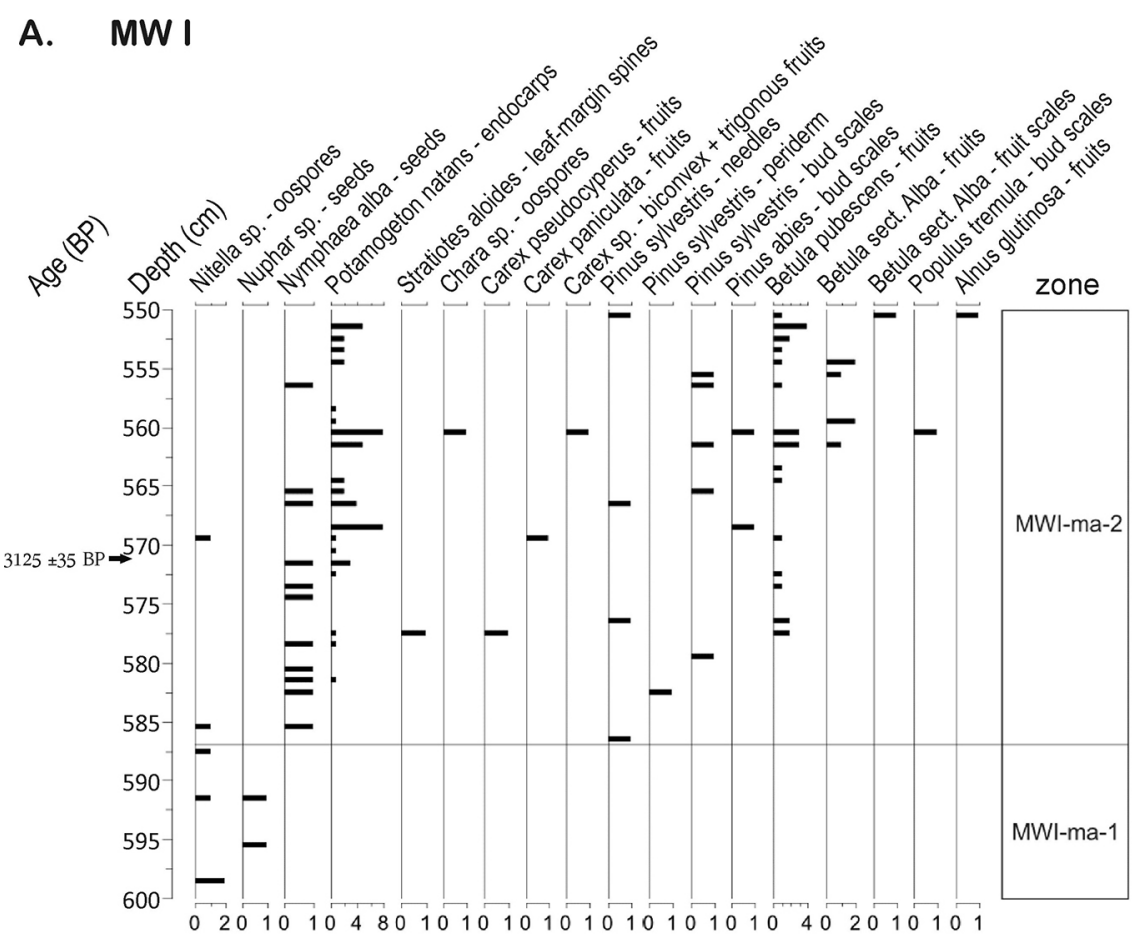

B. MW II

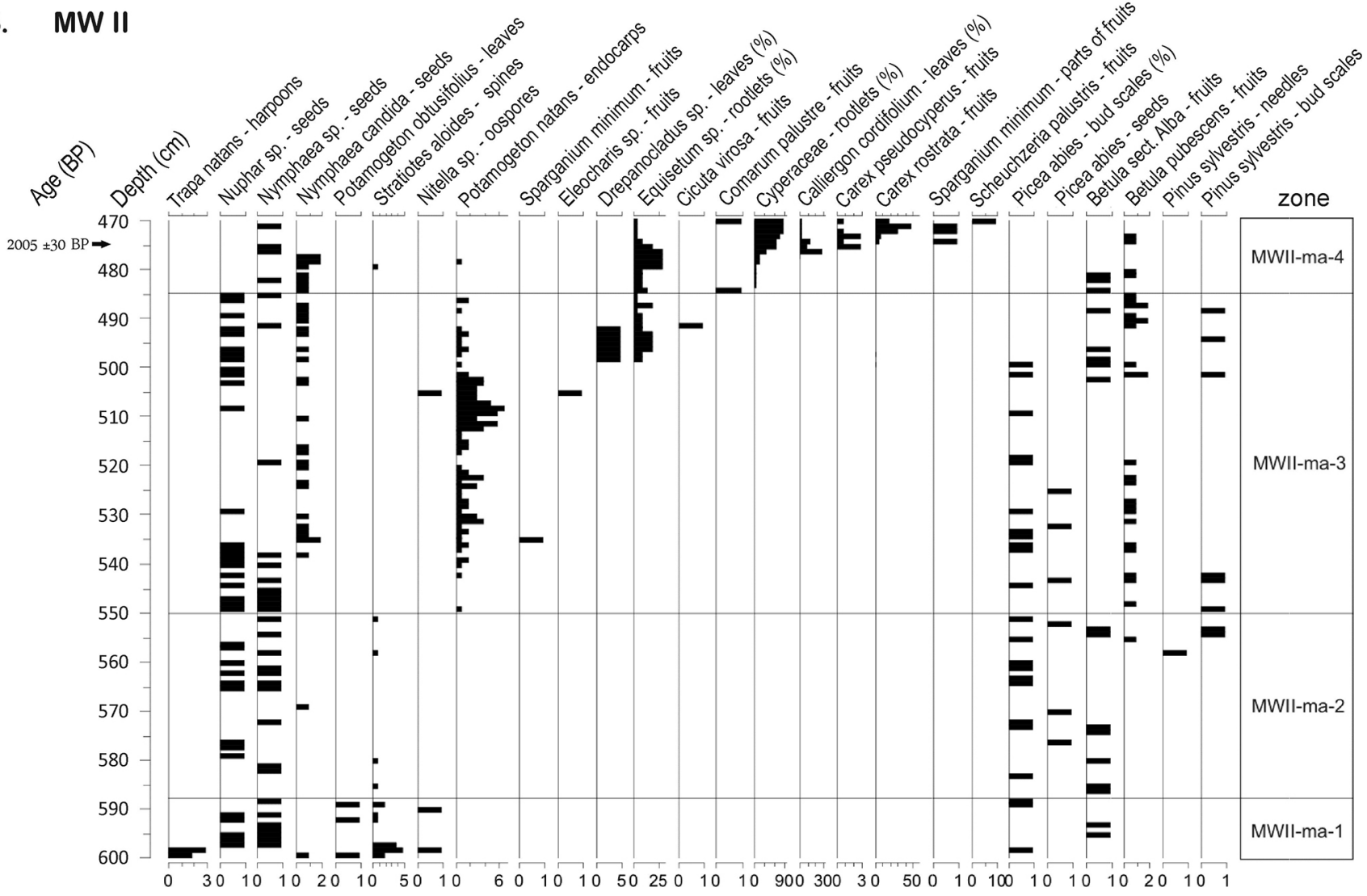

Fig. 2. Plant macrofossil diagrams from Mechacz Wielki bog

A - core MW I, and B - core MW II. Taxa with (\%) are given in estimated volume percentages, others are given in counted numbers (X-axis scale labels; note scale differences) 

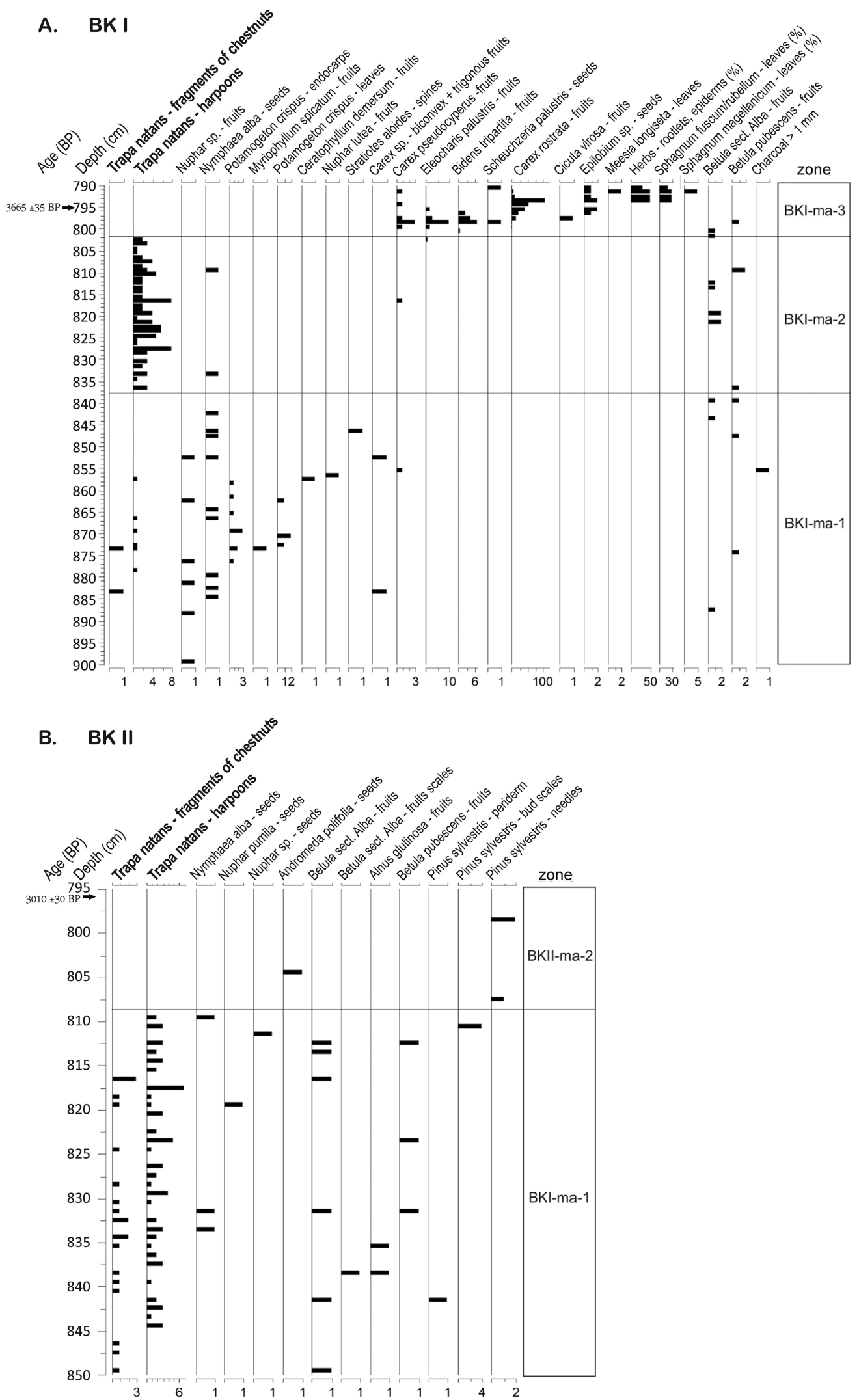

Fig. 3. Plant macrofossil diagrams from Bagno Kusowo bog

A - core BK I, and B - core BK II. Taxa with (\%) are given in estimated volume percentages, others are given in counted numbers (X-axis scale labels; note scale differences) 


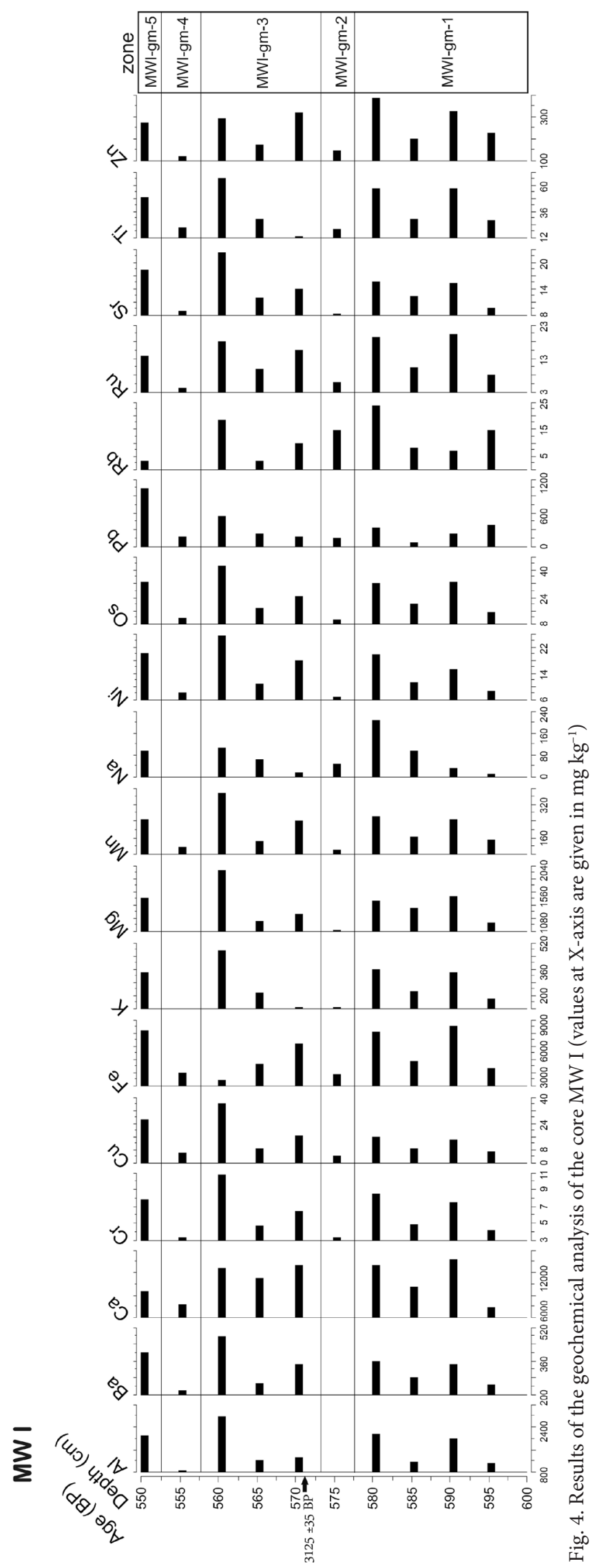



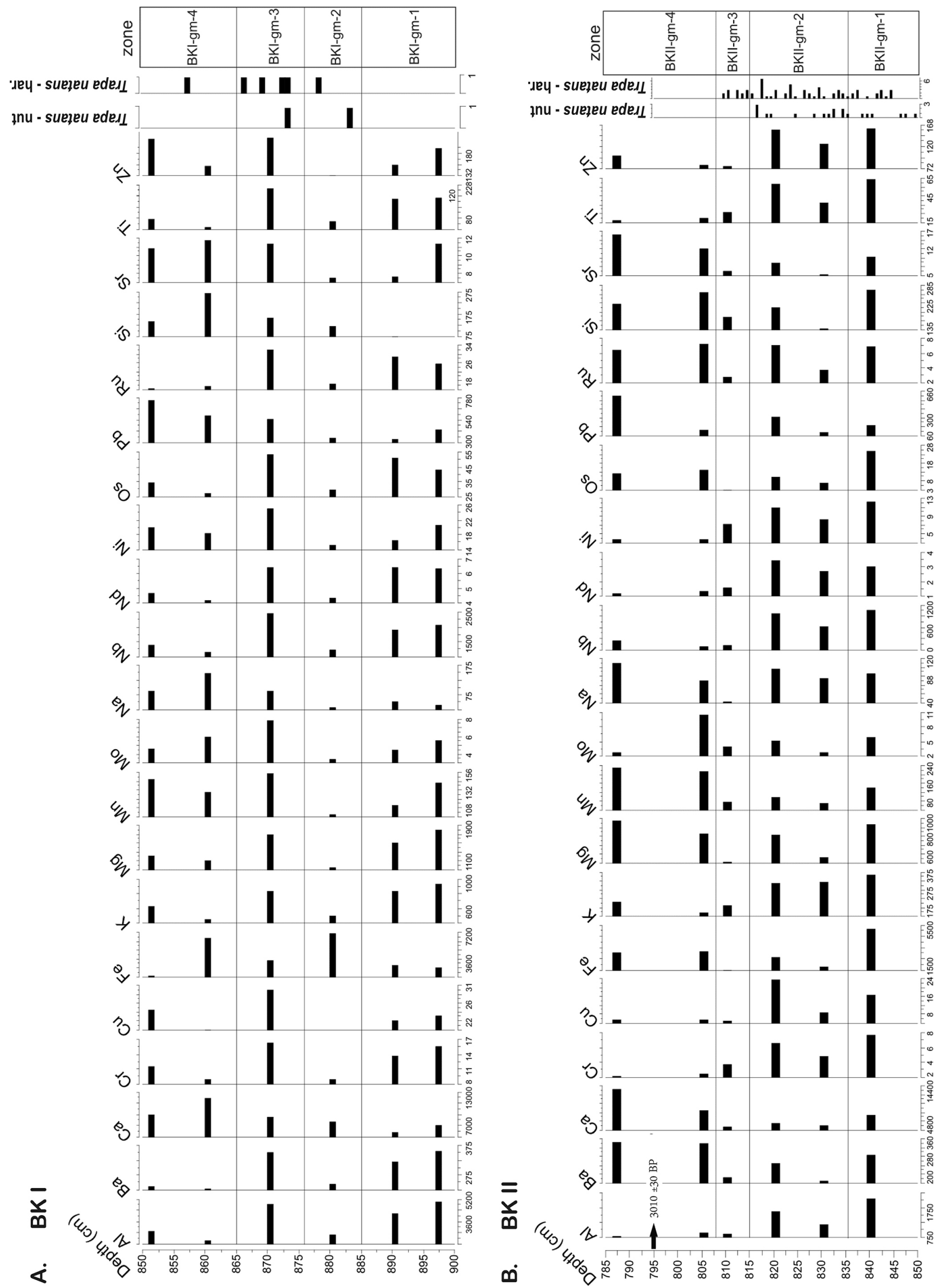
very high $\mathrm{Fe}^{3+}\left(7773 \mathrm{mg} \mathrm{kg}^{-1}\right)$ and $\mathrm{Al}^{3+}\left(2228 \mathrm{mg} \mathrm{kg}^{-1}\right)$ levels, and fairly high values of other elements.

The zone MWI-gm-2 $(577.5 .5-572.5 \mathrm{~cm})$ had the lowest concentrations, including a layer in which $\mathrm{Ca}^{2+}$, and $\mathrm{Al}^{3+}$ were not recorded, and the remaining were only trace elements.

In zone MWI-gm-3 $(572.5-557.5 \mathrm{~cm})$, the elements $\mathrm{w}$ arranged in layers. At a depth of $570.5 \mathrm{~cm}$, they reached the highest concentration values: $\mathrm{Ca}^{2+}(13201$ $\left.\mathrm{mg} \mathrm{kg}{ }^{-1}\right), \mathrm{Fe}^{3+}\left(6451 \mathrm{mg} \mathrm{kg}^{-1}\right)$, and $\mathrm{Al}^{3+}\left(1373 \mathrm{mg} \mathrm{kg}^{-1}\right)$. Slightly lower values were found at $560.5 \mathrm{~cm}$ : $\mathrm{Ca}^{2+}$ (12921 mg kg-1), $\mathrm{Al}^{3+}\left(2835 \mathrm{mg} \mathrm{kg}^{-1}\right)$, and $\mathrm{Fe}^{3+}(2385$ $\left.\mathrm{mg} \mathrm{kg}{ }^{-1}\right)$. The highest $\mathrm{Mg}^{2+}\left(1982 \mathrm{mg} \mathrm{kg}^{-1}\right)$ and $\mathrm{K}^{+}(486$ $\mathrm{mg} \mathrm{kg}{ }^{-1}$ ) levels in the entire core were noted.

Zone MWI-gm-4 (557.5-552.5 cm) was a layer with lower concentration values: $\mathrm{Ca}^{2+}\left(8010 \mathrm{mg} \mathrm{kg}{ }^{-1}\right), \mathrm{Fe}^{3+}$ $3101\left(\mathrm{mg} \mathrm{kg}^{-1}\right)$, a sharp decline of $\mathrm{Al}^{3+}\left(918 \mathrm{mg} \mathrm{kg}^{-1}\right)$, and the lowest $\mathrm{Mg}^{2+}$ level in the entire core $\left(847 \mathrm{mg} \mathrm{kg}^{-1}\right)$.

Zone MWI-gm-5 $(552.5-550 \mathrm{~cm})$ was dominated by $\mathrm{Ca}^{2+}\left(9642 \mathrm{mg} \mathrm{kg}^{-1}\right), \mathrm{Fe}^{3+}\left(8002 \mathrm{mg} \mathrm{kg}^{-1}\right)$ and $\mathrm{Al}^{3+}$ $\left(2147 \mathrm{mg} \mathrm{kg}^{-1}\right)$. Attention was drawn to a high concentration of $\mathrm{Pb}^{2+}\left(1075 \mathrm{mg} \mathrm{kg}^{-1}\right)$. This layer was characterized by periodic increases in most elements. Their highest concentration values were recorded at depths of $550.5 \mathrm{~cm}$ and $560.5 \mathrm{~cm}$.

It follows that the dominant roles in MW I sediments at all levels were played by $\mathrm{Ca}^{2+}, \mathrm{Fe}^{3+}$ and $\mathrm{Al}^{3+}$. In the vertical arrangement, $\mathrm{Ca}^{2+}$ was $52.42 \%$ of all the elements contained in the sediment, followed by the others: $\mathrm{Fe}^{3+}, 25.42 \%$; $\mathrm{Al}^{3+}, 7.89 \% ; \mathrm{Mg}^{2+}, 6.298 \% ; \mathrm{Pb}^{2+}, 1.8 \%$; $\mathrm{Ba}^{2+}, 1.58 \%$; $\mathrm{K}^{+}, 1.28 \%$; $\mathrm{Zn}^{2+}, 1.25 \%$; $\mathrm{Mn}^{2+}, 1.05 \%$; and the remaining elements $<1.00 \%$.

\section{Bagno Kusowo}

Geochemical analysis for BK I sediments was performed for 21 chemical elements. Four zones at BK I and BK II were visually delimited for elements present (Figs 5A and 5B).

In the first zone, BKI-gm-1 $(899.5-885.5 \mathrm{~cm})$, the chemical concentrations in the upper part were low, but in the bottom, these values increased significantly. $\mathrm{Ca}^{2+}\left(7370 \mathrm{mg} \mathrm{kg}^{-1}\right), \mathrm{Al}^{3+}\left(5170 \mathrm{mg} \mathrm{kg}^{-1}\right)$ and $\mathrm{Fe}^{3+}(2699$ $\mathrm{mg} \mathrm{kg}{ }^{-1}$ ) predominated. There was also increased $\mathrm{Mg}^{2+}$ (1827 $\mathrm{mg} \mathrm{kg}^{-1}$ ) and $\mathrm{Mn}^{2+}\left(144 \mathrm{mg} \mathrm{kg}^{-1}\right)$ (Fig. 5A).

Zone BKI-gm-2 $(885.5-875.5 \mathrm{~cm})$ was characterized by the dominance of $\mathrm{Ca}^{2+}\left(7991 \mathrm{mg} \mathrm{kg}^{-1}\right), \mathrm{Fe}^{3+}$ (7151 $\left.\mathrm{mg} \mathrm{kg}^{-1}\right)$ and $\mathrm{Al}^{3+}\left(2734 \mathrm{mg} \mathrm{kg}^{-1}\right)$. The concentration of other elements was low.

In zone BKI-gm-3 $(875.5-865.5 \mathrm{~cm})$, the concentrations of all elements were clearly increased in the middle part of the layer, dominated by $\mathrm{Ca}^{2+}\left(8813 \mathrm{mg} \mathrm{kg}^{-1}\right)$, $\mathrm{Al}^{3+}\left(4913 \mathrm{mg} \mathrm{kg}^{-1}\right)$ and $\mathrm{Fe}^{3+}\left(3586 \mathrm{mg} \mathrm{kg}^{-1}\right)$.

In zone BKI-gm-4 $(865.5-851.5 \mathrm{~cm})$, very high concentrations of $\mathrm{Ca}^{2+}\left(12250 \mathrm{mg} \mathrm{kg}{ }^{-1}\right), \mathrm{Fe}^{3+}(6602 \mathrm{mg}$ $\left.\mathrm{kg}^{-1}\right), \mathrm{Pb}^{2+}\left(605 \mathrm{mg} \mathrm{kg}^{-1}\right), \mathrm{Si}^{4+}\left(273 \mathrm{mg} \mathrm{kg}^{-1}\right)$ and $\mathrm{Na}^{+}$ $\left(153 \mathrm{mg} \mathrm{kg}^{-1}\right)$ were recorded at a depth of $860.5 \mathrm{~cm}$. In the upper layer, $\mathrm{Ca}^{2+}\left(9205 \mathrm{mg} \mathrm{kg}^{-1}\right)$ and $\mathrm{Al}^{3+}(3024 \mathrm{mg}$ $\mathrm{kg}^{-1}$ ) predominated. There was a clear reduction in $\mathrm{Fe}^{3+}$ concentration (1540 $\mathrm{mg} \mathrm{kg}^{-1}$ ), with relatively high $\mathrm{Pb}^{2+}$ (764 $\mathrm{mg} \mathrm{kg}^{-1}$ ) and $\mathrm{Mn}^{2+}\left(149 \mathrm{mg} \mathrm{kg}^{-1}\right.$ ) levels.

Based on our results, the dominant elements in the BK I sediments at all levels were $\mathrm{Ca}^{2+}, \mathrm{Fe}^{3+}$ and $\mathrm{Al}^{3+}$. In the vertical arrangement, $\mathrm{Ca}^{2+}$ represents $44.05 \%$ of the composition, followed by all the elements contained in the sediment: $\mathrm{Fe}^{3+}, 19.84 \%$; $\mathrm{Al}^{3+}, 14.04 \%$; $\mathrm{Nb}^{5+}, 6.44 \%$; $\mathrm{Mg}^{2+}, 6.14 \%$; $\mathrm{K}^{+}, 2.73 \% ; \mathrm{Pb}^{2+}, 2.15 \% ; \mathrm{Ba}^{2+}, 1.57 \%$; $\mathrm{Si}^{4+}$, $1.01 \%$; and the remaining elements $<1.00 \%$.

In zone BKII-gm-1 $(850-835 \mathrm{~cm})$, all the elements reached very high concentrations, especially $\mathrm{Ca}^{2+}(6768$ $\left.\mathrm{mg} \mathrm{kg}{ }^{-1}\right), \mathrm{Fe}^{3+}\left(5262 \mathrm{mg} \mathrm{kg}^{-1}\right)$, and $\mathrm{Al}^{3+}\left(2096 \mathrm{mg} \mathrm{kg}^{-1}\right)$, as well as $\mathrm{Nb}^{5+}\left(1120 \mathrm{mg} \mathrm{kg}^{-1}\right)$ and $\mathrm{Mg}^{2+}\left(950 \mathrm{mg} \mathrm{kg}^{-1}\right)$ (Fig. 5B).

In zone BKII-gm-2 $(835-815 \mathrm{~cm})$ in the lower layer, the elements did not reach high concentrations: $\mathrm{Ca}^{2+}$ (3961 mg kg-1), $\mathrm{Fe}^{3+}\left(1947 \mathrm{mg} \mathrm{kg}^{-1}\right.$ ), and $\mathrm{Al}^{3+}$ (1231 mg $\left.\mathrm{kg}^{-1}\right)$. In the upper layer at a depth of $820 \mathrm{~cm}$, we found $\mathrm{Ca}^{2+}\left(4564 \mathrm{mg} \mathrm{kg}^{-1}\right), \mathrm{Fe}^{3+}\left(2714 \mathrm{mg} \mathrm{kg}^{-1}\right)$, and $\mathrm{Al}^{3+}(1674$ $\left.\mathrm{mg} \mathrm{kg}{ }^{-1}\right)$. An increased $\mathrm{Nb}^{5+}\left(1025 \mathrm{mg} \mathrm{kg}^{-1}\right)$ concentration was noteworthy.

In zone BKII-gm-3 $(815-808.5 \mathrm{~cm})$, the elements had small concentration values: $\mathrm{Ca}^{2+}\left(3591 \mathrm{mg} \mathrm{kg}^{-1}\right)$, $\mathrm{Fe}^{3+}\left(1581 \mathrm{mg} \mathrm{kg}^{-1}\right)$, and $\mathrm{Al}^{3+}\left(912 \mathrm{mg} \mathrm{kg}^{-1}\right)$. T. natans harpoons were found in this layer.

The fourth zone BKII-gm-4 $(808.5-785.5 \mathrm{~cm})$ was characterized by the highest $\mathrm{Ca}^{2+}$ concentration. In the bottom part, $\mathrm{Ca}^{2+}\left(8152 \mathrm{mg} \mathrm{kg}^{-1}\right), \mathrm{Fe}^{3+}\left(3333 \mathrm{mg} \mathrm{kg}{ }^{-1}\right)$ and $\mathrm{Mg}^{2+}\left(848 \mathrm{mg} \mathrm{kg}^{-1}\right)$ prevailed. The ceiling was dominated by $\mathrm{Ca}^{2+}\left(13622 \mathrm{mg} \mathrm{kg}^{-1}\right), \mathrm{Fe}^{3+}\left(3142 \mathrm{mg} \mathrm{kg}^{-1}\right)$, and $\mathrm{Mg}^{2+}\left(986 \mathrm{mg} \mathrm{kg}^{-1}\right)$, with a relatively high $\mathrm{Pb}^{2+}(615 \mathrm{mg}$ $\mathrm{kg}^{-1}$ ) level. Other elements occurred in small amounts in this zone.

This result indicates a dominant role in the BK II sediments (similarly to BK I) at all levels for $\mathrm{Ca}^{2+}, \mathrm{Fe}^{3+}$ and $\mathrm{Al}^{3+}$ in the vertical system. $\mathrm{Ca}^{2+}$ represented $48.85 \%$ of all chemical elements in the sediments, followed by the others: $\mathrm{Fe}^{3+}, 21.60 \% ; \mathrm{Al}^{3+}, 9.23 \% ; \mathrm{Ba}^{2+}, 1.93 \%$; $\mathrm{K}^{+}$, $1.88 \% ; \mathrm{Pb}^{2+}, 1.81 \%$; $\mathrm{Si}^{4+}, 1.56 \% ; \mathrm{Mg}^{2+}, 1.03 \%$ and the remaining elements $<1.00 \%$.

\section{Discussion}

\section{Reasons for the disappearance of Trapa natans}

1. Climate change

Our palaeoecological studies carried out for MW and BK confirmed the occurrence of T. natans in these paleolakes during the Subboreal period. An interesting finding in BK II is the occurrence of Nuphar pumila together with $T$. natans macroremains. The com- 
mon presence of these two plants is very rare because Nuphar pumila, in contrast to T. natans, prefers cool and calcium-free waters (Piękoś-Mirkowa and Mirek 2003). A periodic presence of Nuphar pumila may indicate short-term climate cooling. However, T. natans still occurred and declined later than Nuphar pumila. Based on radiocarbon dating, T. natans disappeared before 4000 years ago on both sites (MW \& BK), in what might be partly linked to the climate cooling documented after ca. 4500 cal. yr BP in this part of Europe (Seppä and Poska 2004; Gałka et al. 2014). Moreover, in the case of MWII, T. natans disappeared long before the disappearance of the lake, so one can exclude the cause of lake terrestrialisation.

The fossil presence of T. natans has been documented in Holocene deposits in many European countries (e.g., Samuelson 1934; Szafer 1954; Godwin 1975; Lang 1994 and papers cited there). In Germany, T. natans fruits have been identified in a few archaeological sites around Lake Federsee. The fossil fruits of T. natans were found in sediment at the bottom of the old lake and along its shoreline. T. natans macrofossils occurred in the layer accumulated from 6019 to 3000 BP. The presence of charred fruits may indicate that they were used for food (Karg 2013). The charred remains of T. natans nuts dated to the beginning of the Subatlantic (approximately 2500 cal. yr BP) were found in Lake Burtnieks in northern Latvia (Ozola et al. 2010). Excavations at a study site in Molino Casarotto in subalpine Italy revealed remnants of water chestnut fruits that date their consumption as far back as ca.5900 BP (Hummel and Kiviat 2004).

T. natans remains have been found in Holocene deposits in Poland: (e.g., Piórecki 1980; Miotk-Szpiganowicz and Gałka 2009; Krechowski et al. 2009; Olszewski and Markowski 2014; Bryl et al. 2014). T. natans came to Poland through the Morawska Gate from southern Europe in the Early Holocene and its distribution was connected to a warmer climate (Kostuch and Misztal 2007; Kowalczyk 2009).

Many authors suggest that the main reason for the disappearance of T. natans coincides with cold climatic stages. Deteriorating climatic conditions at the end of the Subboreal and beginning of Subatlantic periods caused the gradual disappearance of water chestnuts from Finland, northern Russia, and the east Baltic (Hummel and Kiviat 2004; Ozola et al. 2010; Thompson 2014). Climate changes and temperature reduction also had an impact on T. natans germination. The optimal temperature to start germination is $15-23^{\circ} \mathrm{C}$ (Cozza et al. 1994; Bryl et al. 2014).

\section{Terrestrialisation in the lake}

Based on our results at the BK site, we suggest that the decline of T. natans is a consequence of peatland de- velopment. The results of the plant macrofossil analysis proved that $T$. natans was a dominant plant in the paleolake at the BK sites and that its disappearance coincided with the appearance of Carex pseudocyperus, Eleocharis palustris and Bidens tripartita macrofossils. These three plants are common in the transitional zone between lakes and peatland. The development of the peatland with Sphagnum species can lead to gradual acidification and further aggravate the T. natans growth conditions. This phenomenon led to the disappearance of Najas flexilis in the Romincka Forest (Gałka et al. 2012). Currently, these processes are ongoing. Szumirad reservoir (SSW Polska) is decreasing as a result of being filled with sediments deposited by the River Bystrzyna and as a result of natural succession of vegetation, leading to shallowing and overgrowing (Bryl et al 2014), and this effect could have influenced the periodic reduction of $T$. natans in this reservoir. In Lake Opatkowickie (central Poland), due to a reduction in water depth and overgrowing, T. natans is at risk. T. natans coexists with Stratiotes aloides and Spirodela polyrhiza (Krechowski et al. 2009). Small populations of the water chestnut occur in Lake Kozienickie (central Poland). The main danger for T. natans is a strong shallowing of the bay in which the population occurs and competition from other plant species, such as Ceratophyllum demersum and Stratiotes aloides (Krechowski et al. 2009).

Other authors indicate the natural process of lake disappearance as one reason for T. natans decline (Alhonen 1964; Korhola and Tikkanen 1997). For instance, in SW Finland, T. natans macroremains were found in deposits accumulated ca. 3500 cal. yr BP in Pyysuo Lake, a small, shallow, eutrophic lake (Korhola and Tikkanen 1997). The lake, rich in vegetation, turned into a peat bog approximately $2500 \mathrm{cal}$. yr BP as a consequence of overgrowing (Alhonen 1964). In Hungary's Bereg plain, the presence of remains of T. natans in sediments in the period from 6900 to approximately $4550 \mathrm{cal}$. yr BP was recorded (Magyari et al. 2008). The gradual shallowing of the reservoir and development of vegetation such as Polygonum persicaria and Carex pseudocyperus led to the gradual formation of peatland in the period from 2000 to 1000 cal. yr BP.

\section{Competition with other plants}

The optimal conditions for water chestnut development are warm, shallow, eutrophic reservoirs (Kowalczyk 2009). Average annual temperatures, excessively low water temperatures and flow rates may cause T. natans to retreat and encourage the development of other macrophytes. The reduction in the T. natans population is also observed as a consequence of organic sediment deposition in eutrophic reservoirs, in which water exchange takes place every few years. (Piórecki 1980; 
Staniszewski and Zielnica 2006). T. natans can cover the surface of the water reservoir for several vegetation seasons, hindering the heating water. The plant also contributes to shallowing by the production of large quantities of biomass falling to the bottom (Kowalczyk 2009).

T. natans requires an open water reservoir for development and is not able to compete with heliotropes (Zetter and Ferguson 2001). Adverse species for the development of T. natans are Stratiotes aloides, Nymphaea alba, and Nuphar sp., characterized by strong growth and competition with T. natans (Kłosowski and Tomaszewicz 1996), pushing it to deeper places (Zetter and Ferguson 2001; Kamiński 2012).

In BK I, at a depth of $883.5-857.5 \mathrm{~cm}$, the remains of a single $T$. natans were found with other water species such as Nuphar sp. and Nymphaea alba that frequently co-occur and species such as Potamogeton crispus and Ceratophyllum demersum that compete with T. natans.

In the zone from $838.5-801.5 \mathrm{~cm}$, T. natans dominated the aquatic flora. Only single remains of Nymphaea alba survived. The rapid development of rush plants Carex pseudocyperus, Eleocharis palustris, and Carex rostrata at approximately $3670 \mathrm{cal}$. yr BP led to a superseding of $T$. natans.

The remains of plants in the sediments of MW II also confirm the coexistence of T. natans with other plants such as Nitella sp. and Nymphaea candida. The decline of T. natans falls in the period of Stratiotes aloides development, a very expansive thermophilic plant. In the MW I reservoir, we observe the initial development of Nitella sp. and Nuphar sp. followed by Nymphaea alba and Potamogeton natans preventing the development of T. natans.

4. Other reasons for the Trapa natans decline in Poland in the last two centuries

In the vicinity of Szczecin (53⒉ $\left.26^{\prime} 17^{\prime \prime} \mathrm{N} ; 14^{\circ} 32^{\prime} 32^{\prime \prime} \mathrm{E}\right)$, T. natans was present until AD 1870, in Gdańsk Pomerania until 1862, and it disappeared from northeastern Poland after 1872 (Piórecki 1980; Olszewski and Markowski 2014). In the northern part of the country, the vicinity of Szczecin was the last place of T. natans occurrence in the $19^{\text {th }}$ century (Olszewski and Markowski 2014). In the same period, T. natans also occurred in Gdańsk Pomerania (Olszewski and Markowski 2014). Until 1862, T. natans was present in Lake Mirachowskie $\left(54^{\circ} 24^{\prime} 40^{\prime \prime} \mathrm{N}, 1^{\circ} 59^{\prime} 11^{\prime \prime E}\right)$ (Olszewski and Markowski 2014). The work of draining water from the lake led to the disappearance of the species at the above mentioned sites. The presence of T. natans in the vicinity of Mirachów is evidence of the species occurrence throughout the northern part of the country until the mid- $19^{\text {th }}$ century.
The first information about the occurrence of T. natans was in Szumirad reservoir (50 50'14"N; 18 14'59"E) dating back to 1887 (Bryl et al. 2016). In this lake, the species disappearance has been recorded since 1950, despite the fact that its population could have as many as 20000 rosettes. In the years 1976-1977, there were no more rosettes. The reason for the disappearance of $T$. natans was the shallowing and excessive exploitation of the reservoir by a local, now non-existent recreational centre (Bryl et al. 2014). A catastrophic consequence of the disappearance of T. natans in some lakes is also related to the herbivorous white amur fish introduced in the $20^{\text {th }}$ century (Piórecki 1980; Piękoś-Mirkowa and Mirek 2003; Walusiak et al. 2011; Bryl et al. 2014).

Floods can wash off $T$. natans fruits located at the bottom of the research area and remove them to an area not very favourable for the development of the plant (Kamiński 2012).

Water chestnut does not tolerate salinity and does not exist in reservoirs where the sodium chloride concentration exceeds $0.1 \%$. Changes in nutrient content, dehumidification of wetlands and dredging of reservoirs contribute to its extinction. From the analysed literature, T. natans has a high tendency to fluctuate. This observation confirms the extinction of many stations in the San River basin and the Upper Oder, Vistula and the Lusatian Neisse. In the $19^{\text {th }}$ century, T. natans survived in the vicinity of Gdansk and Greater Poland. Between 1970 and 1980, 82\% of the T. natans known in Poland disappeared.

\section{Geochemical parameters of the fossil habitat of Trapa natans}

T. natans is a plant that requires a specific habitat and chemical conditions (Kłosowski and Tomaszewicz 1996). Ecological studies indicate that optimal development occurs in shallow water with high organic matter content that is rich in $\mathrm{Ca}^{2+}$, total $\mathrm{Fe}^{3+}$, and $\mathrm{PO}_{4}^{3-}$ and low in $\mathrm{NH}^{4+}$ and $\mathrm{Mg}^{2+}$ concentrations (Kłosowski and Tomaszewicz 1996; Szańkowski and Kłosowski 1999).

Geochemical analysis conducted in MW I, BK I and BK II show the dominant role of $\mathrm{Ca}^{2+}, \mathrm{Al}^{3+}$ and $\mathrm{Fe}^{3+}$ in all sediments. In MW I, the highest concentrations of $\mathrm{Ca}^{2+}$ and $\mathrm{Fe}^{3+}$ were recorded, preventing T. natans development.

In $\mathrm{BK}$ I sediments, $\mathrm{Ca}^{2+}, \mathrm{Fe}^{3+}$ and $\mathrm{Al}^{3+}$ sustained a high level. There was also significantly elevated $\mathrm{Mg}^{2+}$ and $\mathrm{Na}^{+}$content. Slight traces of T. natans were found in layers with a reduced level of these elements at a depth of 883.5-855.5 cm. Nuphar sp. Nymphaea alba and Potamogeton crispus were better adapted to the environmental changes (Kłosowski and Tomaszewicz 1996). Rapid development of T. natans took place at depth $836.5-802.5 \mathrm{~cm}$, dominating the vegetation and 
almost completely displacing other aquatic species. BK II has similar geochemical parameters to those of BK I. T. natans occurred in the layer with the lowest levels of $\mathrm{Ca}^{2+}, \mathrm{Mg}^{2+}$ and $\mathrm{Na}^{+}$without high $\mathrm{Al}^{3+}$ and $\mathrm{K}^{+}$. In relation to MW I and BK I, the lowest level was also reached by $\mathrm{Fe}^{3+}$. T. natans was accompanied by only a few Nymphaea alba and Nuphar sp. having a wider ecological amplitude of occurrence (Kłosowski and Tomaszewicz 1996).

Present ecological studies also confirm that T. natans populations are well developed in areas with elevated calcium levels (Piórecki 1980; Kłosowski and Tomaszewicz 1996; Szańkowski and Kłosowski 1999; Piękoś-Mirkowa and Mirek 2003). Our research confirms the dominance of calcium in sediments, although its maximum incidence does not coincide with the maximum development of $T$. natans. In the investigated sediments, $\mathrm{Zn}^{2+}$ occurs at different levels. In BK $\mathrm{II}, \mathrm{Zn}^{2+}$ is predominantly located at greater depths as well as in MW I and BK I in higher layers. A very low content of heavy metals such as $\mathrm{Cr}^{2+}, \mathrm{Ni}^{2+}$, and $\mathrm{Cu}^{2+}$ indicates that anthropogenic factors did not play a role in the analysed lakes. This result, however, leads to a high level of $\mathrm{Pb}^{2+}$, reaching $1050 \mathrm{mg} \mathrm{kg}^{-1}$ in MW I and 780 mg kg-1 in BK I. $\mathrm{Pb}^{2+}$ is a heavy metal, poorly migrating, therefore its natural content in the soil reflects its content in content in host rocks. T. natans in the BK II core occurs at depths of $808.5-849.5 \mathrm{~cm}$. The highest values of practically all the elements were observed in this core; however, they cannot be correlated with the occurrence of T. natans because the layers with elevated values are beyond the reach of T. natans macroremains $(805.5 \mathrm{~cm})$.

\section{Conclusions}

Our palaeoecological studies (plant macrofossils and geochemical analysis) allowed us to determine the age and causes of T. natans decline as well as to reconstruct its subfossil habitat in two formed lakes in northern Poland presently occupied by the Baltic raised bogs Mechacz Wielki (MW) and Bagno Kusowo (BK).

1. The decline of $T$. natans took place approximately 3440-3240 cal. yr BP at MW and approximately 4090-3890 cal. yr BP at BK.

2. The climate cooling at the end of the Subboreal period could be the reason for the disappearance of $T$. natans at MW.

3. In BK I and MW, lake transformation took place. The presence of rush plants, e.g., Eleocharis sp., Carex rostrata, and Carex pseudocyperus, documents the shallowing of the lake at Bagno Kusowo. A rapid spread of Nuphar sp. and Nymphaea candida eliminated T. natans in MW. Additionally, the massive appearance of Potamogeton natans contributed to the production of large amounts of biomass deposited to the bottom, resulting in a shallowing of the lake and the development of rush vegetation.

4. Geochemical analyses conducted in MW I, BK I and BK II showed the dominant role of $\mathrm{Ca}^{2+}, \mathrm{Al}^{3+}$ and $\mathrm{Fe}^{3+}$ in all sediments. The highest concentrations of $\mathrm{Ca}^{2+}$ and $\mathrm{Fe}^{3+}$ were recorded in MW I. However, it is not possible to correlate the high values of these chemical elements with the development of $T$. natans because the level of their concentration does not coincide with its maximum development. In BK II, T. natans reached the peak of development at a $\mathrm{Ca}^{2+}$ concentration of $4000-5000 \mathrm{mg} \mathrm{kg}^{-1}$. At a very large $\mathrm{Ca}^{2+}$ concentration, T. natans did not occur as it did in the case of high $\mathrm{Fe}^{3+}, \mathrm{Al}^{3+}$ and $\mathrm{Mg}^{2+}$, and, what is interesting, almost all the aquatic plants died.

5. Palaeobotanical analysis indicates that both lakes were shallow, eutrophic reservoirs overgrown by various macrophytes. T. natans was the dominant plant in both lakes during its prevalence accompanied by a few Nymphaea candida, Potamogeton obtusifolius, Stratiotes aloides (MW II), Potamogeton crispus (BK I) and Nymphaea alba (BK II). The common occurrence of T. natans with Nuphar pumila (BK II) was also recorded, which is a rare phenomenon because these plants have different ecological requirements.

\section{Acknowledgements}

The study was financed through a grant from the National Science Centre (Poland) awarded for the following projects: (No. NN 305062 240) and No UMO2016/23/B/ST10/00762 (PI: Mariusz Gałka). The assistance of Karol Jakubowski and Jędrzej Proch is greatly acknowledged while conducting laboratory works.

\section{References}

Ali Y., Javed K., 2014, Trapa natans L. root extract suppresses hyperglycemic and hepatotoxic effects in STZ-induced diabetic rat model, J. Ethnopharmacol. 151(2): 931-936.

Alhonen P., 1964, Radiocarbon age of water nut (Trapa natans L.) in the sediments of Lake Karhejarvi, SW-Finland, Mem. Soc. Fauna Flora Fenn. 40: 192-197.

Arima S., Daigoho M., Hoque A., 1999, Flower development and an thesis behavior in the water chestnut (Trapa sp.), Agric. Bull. Saga Univ. 84: 83-92.

Baldantoni D., Alfani A., Di Tommasi P., Bartoli G., De Santo A.V., 2004, Assessment of macro and microelement accumulation capability of two aquatic plants, Environ. Pollut. 130(2): 149-156.

Bharthi V., Kavya B., Shantha T.R., Reddy M.P, Kavya N., Rao V.R., Ishnawa K.B., Venkateshwarlu G., 2015, Pharmacognostical evaluation and phytochemical studies 
on Ayurvedic nutritional fruits of Trapa natans L, Int. J. Herb. Med. 3(5): 13-19.

Berglund B.E, Gaillard M-J., Björkman L., Persson T., 2008, Long-term changes in floristic diversity in southern Sweden: palynological richness, vegetation dynamics and land-use, Veget. Hist. Archaeobot. 17(5): 573-583.

Bradshaw A.D., McNeilly T., 1991, Evolutionary response to global climatic change, Ann. Bot. 67(Suppl. 1): 5-14.

Bronk R.C., 2009, Bayesian analysis of radiocarbon dates, Radiocarbon 51(1): 337-360.

Bryl Ł., Jusik S., Staniszewski R., Achtenberg K., 2016, Charakterystyka roślinności wodnej zbiornika Szumirad (woj. opolskie) w 2014 roku, ze szczególnym uwzględnieniem kotewki orzecha wodnego Trapa natans L. (Characteristics of aquatic vegetation of the Szumirad reservoir (Opolskie voivodeship) in 2014, with particular emphasis on the Trapa natans L.), Prz. Przyr. 27(1): 31-46 (in Polish, English summary).

Cedro A., Sotek Z., 2016, Natural and anthropogenic transformations of a baltic raised bog, Forest 7: 2-14.

Ciaciura A., Wilhel M., 2005, Turzyca bagienna Carex limosa na torfowisku Kusowskie Bagno (Carex limosa at the Kusowskie Bagno peat bog), Chrońmy Przyr. Ojcz. 61(3): 31-36 (in Polish, English summary).

Cozza R., Galanti G., Botonti B., Innocenti A., 1994, Effect of Storage at low Temperature on the Germination of the Water chestnut (Trapa natans L.), Phyton 34(2): 315-320.

Davidson T.A., Sayer C.D., Bennion H., David C., Rose N., Wade M.P., 2005, A 250 year comparison of historical, macrofossil and pollen records of aquatic plants in a shallow lake, Freshwater Biol. 50(10): 1671-1686.

Džigurski D., Ljevnaić-Mašić B., Nikolić L., 2012, Trapetum natantis Müller et Görs 1960 in hydro meliorative facilities in Serbia, Acta Soc. Bot. Pol. 82(2): 125-133.

Flenley J.R., Maloney B.K., Ford D., Hallam G., 1975, Trapa natans in the British Flandrian, Nature 257: 39-41.

Gałka M, Tobolski K, Kołaczek P., 2012, The Holocene decline of Spender naiad (Najas flexilis (Willd) Rostk \& W.L.E. Schmidt) in NE Poland in the light of new palaeobotanical data, Acta Palaeobot. 52(1): 127-138.

Gałka M., Tobolski K., Zawisza E., Goslar T., 2014, Postglacial history of vegetation, human activity and lake-level changes at Jezioro Linówek in northeast Poland, based on multi-proxy data, Veget. Hist. Archaeobot. 23(2): 123-152.

Gałka M., Tobolski K., Lamentowicz Ł., Ersek V., Jassey V.E.J., van der Knaap W.O., Lamentowicz M., 2017, Unveiling exceptional Baltic bog ecohydrology, autogenic succession and climate change during the last 2000 years in CE Europe using replicate cores, multi-proxy data and functional traits of testate amoebae, Quat. Sci. Rev. 156: 90-106.

Godwin H., 1975, The history of the British Flora, Cambridge University Press, Cambridge, $541 \mathrm{pp}$.

Herbichowa M., Pawlaczyk P., Stańko R., 2007, Ochrona wysokich torfowisk bałtyckich na Pomorzu. Doświadczenia i rezultaty projektu LIFE04NAT/PL/000208 PLBALTBOGS (Conservation of Baltic raised bogs in Pomerania, Poland. Experience and results of the LIFE04NAT/ PL/000208 PLBALTBOGS Project), Wydaw. Klubu Przyrodników, Świebodzin, 147 pp (in Polish and English).

Hummel M., Kiviat E., 2004, Review of World Literature on Water Chestnut with Implications for Management in North America, J. Aquat. Plant Manage. 42: 17-28.

Hussner A., Stiers I., Verhofstad M.J.J.M., Bakker E.S., Grutters B.M.C., Haury J., van Valkenburgf J.L.C.H., Brundu G., Newman J., Clayton J.S., Anderson L.W.J., Hofstra D., 2017, Management and control methods of invasive alien fresh water aquatic plants, Aquat. Bot. 136: 112-137.

Jakubowska A., Kazuń A. 2005, A locality of Water Chestnut Trapa natansL. (Trapaceae) in the Odra oxbow lake near Zakrzów (Oława district), Acta Bot. Siles. 2: 155-158.

Juggins S., 2003, C2 user guide. Software for ecological and paleoecological data analysis and Visualization, Newcastle University, Newcastle upon Tyne, 73 pp.

Karg S., 2013, The water chestnut (Trapa natans L.) as a food resource during the $4^{\text {th }}$ to $1^{\text {st }}$ millennia $\mathrm{BC}$ at Lake Federsee, Bad Buchau (southern Germany), Environ. Archaeol. 11(1): 125-130.

Kamiński R., 2012, Kotewka orzech wodny Trapa natans L. s. 1. (Water chestnut Trapa natans L. s. l.), [in:] Perzanowska J. (ed.) Monitoring gatunków roślin. Przewodnik metodyczny. Część III (Monitoring of plant species. Methodological guide. Part III), GIOŚ, Warszawa: 128-143 (in Polish).

Kaźmierczakowa R., Zarzycki K. (eds), 2001, Polska czerwona księga roślin. Paprotniki i rośliny kwiatowe (Polish Red Book of Plants. Pteridophytes and flowering plants), Inst. Bot. PAN, Kraków: 260-261 (in Polish).

Kłosowski S., Tomaszewicz H., 1996, Zur Ökologie des Trapetum natantis und des Nymphoidetum peltatae in Polen (On the ecology of Trapetum natantis and Nymphoidetum peltatae in Poland), Tuexenia 16: 105-116 (in German).

Kołaczek P., Margielewski W., Gałka M., Apolinarska K., Płóciennik M., Gąsiorowski M., Buczek K., Karpińska-Kołaczek M., 2017, Five centuries of the Early Holocene forest development and its interactions with paleo ecosystem of small landslide lake in the Beskid Makowski Mountains (Western Carpathians, Poland). High resolution multiproxy study, Rev. Paleobot. Palynol. 244: 113-127.

Kondracki J., 2009, Geografia regionalna Polski (Regional geography of Poland), Wydaw. Nauk. PWN, Warszawa, 468 pp (in Polish).

Korhola A.A., Tikkanen M.J., 1997, Evidence for a more recent occurrence of water chestnut (Trapa natans L.) in Finland and its palaeoenvironmental implications, Holocene 7(1): 39-44.

Kostrakiewicz K., Kozak M., 2009, Nowe, obfite stanowisko kotewki orzecha wodnego Trapa natans L. na Opolszczyźnie (A newly numerous population of water chestnut Trapa natans L. in the Opole province, SW Poland), 
Chrońmy Przyr. Ojcz. 65(1): 61-64 (in Polish, English summary).

Kostuch R., Misztal A., 2007, Roślinność kserotermiczna istotnym elementem bioróżnorodności Wyżyny Małopolskiej (Xerothermic vegetation as in important element of biodiversity of the Małopolska Upland), Woda Środ. Obsz. Wiej. 7(2b): 61-73 (in Polish, English summary).

Kowalczyk B., 2009, Stanowisko kotewki orzecha wodnego (Trapa natans) w Kuźni Nieborowskiej (Kotlina Raciborska) Locality of water chestnut (Trapa natans) in Kuźnia Nieborowska, Raciborska Valley), Ann. Acad. Med. Siles. 63(2): 36-39 (in Polish, English summary).

Krechowski J., Piórek K., Ciosek M., 2009, Kotewka orzech wodny Trapa natans L. i inne interesujące gatunki roślin naczyniowych w szacie roślinnej Jeziora Opatkowickiego i Kozienickiego, Nizina Środkowomazowiecka (Trapa natans L. and other interesting vascular plant species in the vegetation of the Opatkowickie and Kozienickie Lakes, the Nizina Środkowomazowiecka Lowland, central Poland), Chrońmy Przyr. Ojcz. 65(6): 449-454 (in Polish, English summary).

Kuneš P., Pokorny P., Šida P., 2008, Detection of the impact of early Holocene hunter-gatherers on vegetation in the Czech Republic, using multivariate analysis of pollen, Veg. Hist. Archaeobot. 17: 269-287.

Lamentowicz M., Gałka M., Lamentowicz Ł., Obremska M., Kuehl N., Luecke A., Jassey V.E., 2015, Reconstructing climate change and ombrotrophic bog development during the last 4000 years in northern Poland using biotic proxies, stable isotopes and trait-based approach, Palaeogeogr. Palaeoclimatol. Palaeoecol. 418: 261-277.

Lang G., 1994, Quartäre Vegetationsgeschichte Europas: Methoden und Ergebnisse (Quaternary vegetation history of Europe. Methods and results), Gustav Fischer Verlag, Jena-Stuttgart-New York, 462 pp (in German).

Ławicki Ł., Marchowski D., Ziarnek K., 2017, Powrót kotewki orzecha wodnego Trapa Natans do doliny dolnej Odry (Return of the Water Caltrop Trapa natans to the Lower Odra River Valley), Prz. Przyr. 28(3): 3-10 (in Polish, English summary).

Łuczaj Ł., 2008, Dziko rosnące rośliny jadalne w ankiecie Józefa Rostafińskiego z roku 1883 (Wild edible plants in Józef Rostafiński’s questionnaire of 1883), Wiad. Bot. 52(1/2): 39-50 (in Polish, English summary).

Magyari E. K., Jakab G., Sümegi P., Szöör Gy., 2008, Holocene vegetation dynamics in the Bereg Plain, NE Hungary the Báb-tava pollen and plant macrofossil record, Acta Geograph. Geol. Meteorol. Debr. 3: 33-50.

Martín-Closas C., 2013, The fossil record and evolution of fresh water plants: A review, Geol. Acta 1(4): 315-338.

Marquer L., Gaillard M-J., Sugita S., Poska A., Trondman A-K., Mazier F., Nielsen A.B., Fyfe R.M., Jönsson A.M.,Smith B., Kaplan J.O., Alenius T., Birks H.J.B., Bjune A.E., Christiansen J., Dodson J., Edwards K.J., Giesecke T., Herzschuh U., Kangur M., Koff T., Latałowa M., Lechterbeck J., Olofsson J., Seppä H., 2017, Quantifying the effects of land use and climate on Holocene vegetation in Europe, Quat. Sci. Rev. 171: 20-37.

Mirek Z., Piękoś-Mirkowa H., Zając A., Zając M., 2002, Flowering Plants and Pteridophytes of Poland. A Checklist, Inst. Bot. PAN, Kraków, 442 pp.

Miotk-Szpiganowicz G., Gałka M., 2009, A new site of Holocene fossil Trapa natans L. at the Kaszuby Lakeland (Poland), Limnol. Rev. 9(4): 165-173.

Nienhuis P.H., Bakker J.P., Grootjans A.P., Gulati R.D., de Jonge V.N., 2002, The state of the art of aquatic and semiaquatic ecological restoration projects in the Netherlands, Hydrobiologia 478(1-3): 219-233.

Normand S., Ricklefs R.E, Skov F., Bladt J., Tackenberg O., Svenning J-Ch., 2011, Postglacial migration supplements climate in determining plant species ranges in Europe, Proc. R. Soc. B 278: 3644-3653.

Olszewski T., Markowski R., 2014, Trapa natans L. s. 1. jako wymarły w XIX w. składnik flory Pomorza Gdańskiego (Trapa natans L. s. L. as extinct in the $19^{\text {th }}$ century component of Gdańsk Pomerania flora), Acta Bot. Cassub. 6: 153-156 (in Polish, English summary).

Ozola I., Cerina A., Kalnina L., 2010, Reconstruction of palaeovegetation and sedimentation conditions in the area of ancient Lake Burtnieks, northern Latvia, Est. J. Earth Sci. 59(2): 164-179.

Petrović D., Jančić D., Furdek M., Mikac N., Krivokapić S., 2016, Aquatic plant Trapa natans L. as bioindicator of trace metal contamination in a freshwater lake (Skadar Lake, Montenegro), Acta Bot. Croat. 75(2): 236-243.

Perzanowska J. (ed.), 2012, Monitoring gatunków roślin. Przewodnik metodyczny. Część III (Monitoring of plant species. Methodological guide. Part III), GIOŚ, Warszawa, 268 pp (in Polish).

Piękoś-Mirkowa H., Mirek Z., 2003, Atlas roślin chronionych (Atlas of protected plants), Multico, Warszawa, $584 \mathrm{pp}$ (in Polish).

Piórecki J., 1980, Kotewka - Orzech wodny (Trapa L.) w Polsce (Water chestnut (Trapa L.) in Poland), Biblioteka Przemyska, Przemyśl, 159 pp (in Polish).

Reimer P.J., Bard E., Bayliss A., Beck J.W., Blackwell P.G., Bronk Ramsey C., Buck C.E., Cheng H., Edwards R.L., Friedrich M., Grootes P.M., Guilderson T.P., Haflidason H., Hajdas I., Hatte C., Heaton T.J., Hoffmann D.L., Hogg A.G., Hughen K.A., Kaiser K.F., Kromer B., Manning S.W., Niu M., Reimer R.W., Richards D.A., Scott E.M., Southon J.R., Staff R.A., Turney C.S.M., van der Plicht J., 2013, IntCal13 and Marine13 Radiocarbon Age Calibration Curves 0-50,000 Years cal BP, Radiocarbon 55(4): 1869-1887.

Samuelsson G., 1934, Die Verbreitung der höheren Wasser pflanzen in Nordeuropa, Fennoskandinavien und Danemark (The distribution of higher water plants in Northern Europe, Fennoscandia and Denmark), Acta Phytogeogr. Suec. 6: 5-211 (in German).

Smieja A., Ledwoń M., 2013, Reintrodukcja kotewki orzecha wodnego Trapa natans w Kotlinie Oświęcimskiej (Re- 
introduction of water chestnut Trapa natans in the Oswiecim Basin), Chrońmy Przyr. Ojcz. 69(6): 475-482 (in Polish, English summary).

Seppä H., Poska A., 2004, Holocene annual mean temperature changes in Estonia and their relationship to solar insolation and atmospheric circulation patterns, Quat. Res. 61(1): 22-31.

Staniszewski R., Zielnica J., 2006, Ocena możliwości przywrócenia kotewki orzecha wodnego (Trapa natans) do wód Wielkopolski (Estimation of the possibility of restitution of water chestnut (Trapa natans L.) population in freshwaters of Wielkopolska), Pr. Komis. Nauk Rol. Leśn. PTPN 100: 131-137 (in Polish, English summary).

Szafer W., 1954, Plioceńska flora okolic Czorsztyna i jej stosunek do plejstocenu (Pliocene flora from the vicinity of Czorsztyn, West Carpathians, and its relationship to the Pleistocene), Pr. Inst. Geol. 11: 1-238 (in Polish).

Szańkowski M., Kłosowski S., 1999, Habitat conditions of nymphaeid associations in Poland, [in:] Caffrey J., Barrett P.R.F., Ferreira M.T., Moreira I.S., Murphy K.J., Wade P.M. (eds), Biology, Ecology and Management of Aquatic Plants. Developments in Hydrobiology, Vol. 147, Springer, Dordrecht: 177-185.

Thompson E.O., 2014, A review on climate change effects on vegetation - Past and future, Int. J. Ecol. Sci. Environ. Eng. 1(2): 27-42.

Tobolski K., 2000, Przewodnik do oznaczania torfów i osadów jeziornych (Guide to determination of peat and lake sediments), Wydaw. Nauk. PWN, Warszawa, 508 pp (in Polish).

Tornadore N., Marcucci R \& Marchiori S., 2000, Karyology, pollen and seed morphology, and distribution of eight endangered species in the Veneto region (Northern Italy), Plant Biosyst. 134(1): 71-82.

Väliranta M., Salonen J.S., Heikkilä M. L., Amon L., Helmens K., Klimaschewski A., Kuhry P., Kultti S., Poska A., Shala
S., Veski S., Birks H.H., 2015, Plant macrofossil evidence for an early onset of the Holocene summer thermal maximum in northernmost Europe, Nat. Commun. Nature Communication 6: 6809.

Velichkevich F. YU., Zastawniak E., 2008, Atlas of the Plejstocene vascular plant macrofossils of Central and Eastern Europe. Part 2 - Herbacous dicotyledons, Inst.Bot. PAN, Kraków, 380 pp.

Walusiak E., Wilk-Woźniak E., Pociecha A., Ciszewski D., 2011, Nowe stanowiska kotewki orzecha wodnego Trapa natans i Salwinii pływającej Salvinia natans w okolicach Chrzanowa i Niepołomic (New localities of Trapa natans and Salvinia Natans in the Chrzanów and Niepołomice environs), Chrońmy Przyr. Ojcz. 67(2): 189-192 (in Polish, English summary).

Woś A., 1993, Regiony klimatyczne Polski w świetle częstości występowania typów pogody (Climatic regions of Poland in the light of the frequency of various weather types), Zesz. IGiPZ PAN 20: 5-91 (in Polish, English summary).

Yang X., Wu X., Hao H., He Z., 2008, Mechanisms and assessment of water eutrophication, J. Zhejiang Univ. Sci B 9(3): 197-209.

Zając A., Zając M.(eds), 2001, Atlas rozmieszczenia roślin naczyniowych w Polsce (Distribution Atlas of Vascular Plants in Poland), Inst. Bot. UJ, Kraków, 716 pp (in Polish).

Zetter R., Ferguson D., 2001, Trapaceae pollen in the Cenozoic, Acta Palaeobot. 41(2): 321-339.

Żurek S., Kloss M., 2012, Torfowiska zachodniej części Puszczy Rominckiej ze szczególnym uwzględnieniem rezerwatu Mechacz Wielki (Peatlands of W Romincka Forest, general remarks and a case study of the Reserve Mechacz Wielki), Stud. Limn. Tel. 6(2): 73-86 (in Polish, English summary). 